\title{
CENOTES - LAKES OF THE YUCATAN PENINSULA (MEXICO)
}

\author{
Krystyna Szeroczyńska, Edyta Zawisza \\ Institute of Geological Sciences, Polish Academy of Sciences, Twarda 51/55, 00-818 Warsaw, Poland; \\ kszerocz@twarda.pan.pl,ezawisza@twarda.pan.pl
}

\begin{abstract}
Cenote lakes are natural sinkholes or depressions resulting from the collapse of limestone bedrock exposing the groundwater underneath. Thousands of such lakes are particularly encountered on the Yucatan Peninsula (Mexico). These lakes were of great significance for the Maya culture as important religious places and primary source of drinking water. They permitted the survival of Mayan communities through dry periods known as "Maya drought". Most of the cenote lakes are large open water pools measuring tens of meters in diameter. The majority of cenotes are smaller sheltered sites. Their waters are usually very clear and oligotrophic, originating from rain water filtering slowly through the ground. The authors visited and collected zooplankton samples from eight cenotes in November 2013, namely: Ik-Kil, Samula, Zaci, X-Kekn, Actum Ha, Cristal, Sian Ka'an, and Chan Chemuxil (transect Merida-TulumCancun). The analysed lakes differ considerably in morphological terms, varying from very deep to shallow. Some of them are under human impact (tourists). The water samples were analysed for zooplankton content, but the phytoplankton frequently occurring was also taken into account. The obtained results are largely varied, indicated big ecological verity among cenotes which depended on lake age, localization and morphometry. As showed our study Cladocera zooplankton was very rare and only present at several sites. Between the fauna community Copepoda and Ostracoda species were the most abundant. Phytoplankton were present in all studied lakes and it sees that played the central role in those ecosystems.
\end{abstract}

Key words: cenotes, Yucatan, Mexico, phytoplankton, zooplankton.

Manuscript received 5 January 2015, accepted

\section{INTRODUCTION}

A cenote is a natural phenomenon described by Back (1995) and Stoessell et al. (1993) as a sinkhole in the Earth's surface. Thousands of them are encountered in southern Mexico on the Yucatan Peninsula. They are distributed from the central region to the coastal area of the peninsula, and many are as well situated on the western Caribbean wetlands. Similar lakes (karst wells) occur in Australia, Cuba, Turkey, Europe and Ural region (Back and Hanshaw, 1970). On the Yucatan Peninsula, however, they are particularly numerous (their number is estimated for more than 5000), whereas they are very rare in other parts of the world.

In geological terms, the Yucatan Peninsula is exclusively composed of carbonate rocks, subject to strong karstification in the Miocene-Pleistocene (Back and Hanshaw, 1970). The karst processes contributed to the origin of numerous caves and underground corridors, where the collapse of the ceiling resulting development of natural wells filled with water (Perry et al., 1996; Steinich et al., 1996). In South Mexico those lakes are called cenote what comes from the word $d z$ 'onot, meaning "a cave with accumulated water" in the Mayan language. The lakes have varied sizes and depths. Many of them are shallow and small or very deep lakes (some reaching one hundred metres in depth), or extensive lagoons with gentle slopes (named aguadas). The size and morphometry of cenote lakes mostly depend on their age. The unique feature of the Yucatan Peninsula, resulting from its karstic nature, is lack of surface rivers (Torres-Talamante et al., 2011). This makes cenotes extremely important in ecological, economical, and cultural terms. Cenote lakes played an important role for the Maya civilization. They were called Xibalby, what means gates to the underground world. Cities and religious centres of the Mayas developed around the mentioned lakes, considered the places of residing of the god of rain, Chaac. Cenotes were the only sources of freshwater for the Yucatan Peninsula inhabitants throughout the hundreds of years. Local indigenous consider those lakes a secret places which permit survival of their civilisation even catastrophic dry periods known as "Maya drought".

Cenotes lakes are characterized by stable hydrological conditions, and very low water fluctuations between wet and dry seasons (Sanchez et al., 2002). Almost all of them present very good water quality due to their oligotrophic status. Water transparency and colour particularly depended on the access of sunlight (Cervantes-Martinez, 2002). Today, cenotes are still important as a water supply for local indigenous communities. Although they constitute an important element of 


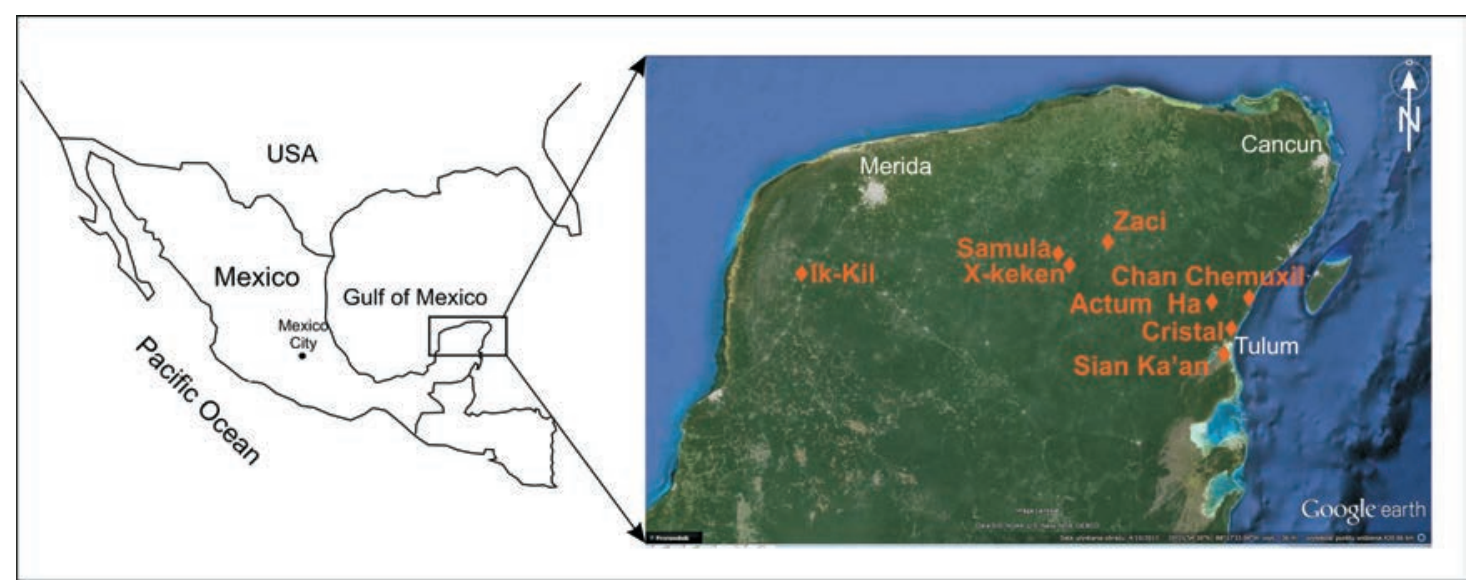

Fig. 1. Location of sampling cenotes (northern Yucatan, Mexico), name of cenotes in orange.

the Yucatan Peninsula, only few scientific studies concerning their genesis and hydrobiological data have been conducted so far (Alcocer et al., 1998; Schmitter-Soto et al., 2002; Elías-Gutiérrez et al., 2006; Torres-Talamante et al., 2011).

The objective of this paper is to provide a brief overview regarding zooplankton collected in November 2013, and to describe the cladoceran community of eight cenotes located in the north of the Yucatan Peninsula. In general Cladocera fauna occurring in the tropical regions has been studied to very little extend, and research on the species composition of this group in the cenote lakes has been sporadic so far (ElíasGutiérrez et al., 2006; Smirnov and Elías-Gutiérrez , 2011). During the study also phytoplankton frequently occurring in the samples was taken into account. The paper presents the comparison of the results regarding the cladoceran structure obtained in particular cenotes, and their discussion in reference to the limited literature data.

\section{STUDY AREA}

The zooplankton study was conducted in eight cenotes

Table 1 List of analysed lakes with their geographical coordinates and general morphometric data

\begin{tabular}{|c|c|c|c|c|c|}
\hline No. & Name of lake & Coordinates & $\begin{array}{c}\text { Maximum } \\
\text { depth }(\mathrm{m})\end{array}$ & Type & $\begin{array}{c}\text { Sampling } \\
\text { date }\end{array}$ \\
\hline 1 & IK-KIL & $\begin{array}{c}20^{\circ} 21.500^{\prime} \mathrm{N} \\
89^{\circ} 46.323^{\prime} \mathrm{W}\end{array}$ & 90 & $\begin{array}{c}\text { sinkhole } \\
\text { (open) }\end{array}$ & 6.11 .2013 \\
\hline 2 & ZACI & $\begin{array}{l}20^{\circ} 39.636^{\prime} \mathrm{N} \\
88^{\circ} 33.036^{\prime} \mathrm{W}\end{array}$ & 22 & $\begin{array}{c}\text { sinkhole } \\
\text { (open) }\end{array}$ & 7.11 .2013 \\
\hline 3 & SAMULA & $\begin{array}{l}20^{\circ} 39.762^{\prime} \mathrm{N} \\
88^{\circ} 14.702^{\prime} \mathrm{W}\end{array}$ & 25 & $\begin{array}{c}\text { sinkhole } \\
\text { (cave) }\end{array}$ & 7.11 .2013 \\
\hline 4 & X-KEKEN & $\begin{array}{l}20^{\circ} 39.681^{\prime} \mathrm{N} \\
88^{\circ} 14.571^{\prime} \mathrm{W}\end{array}$ & 4.7 & $\begin{array}{c}\text { sinkhole } \\
\text { (cave) }\end{array}$ & 7.11 .2013 \\
\hline 5 & ACTUM HA & $\begin{array}{c}20^{\circ} 16.467^{\prime} \mathrm{N} \\
87^{\circ} 29.177^{\prime} \mathrm{W}\end{array}$ & 2 & $\begin{array}{c}\text { pool (be- } \\
\text { fore cave) }\end{array}$ & 8.11 .2013 \\
\hline 6 & CHEM & $\begin{array}{l}20^{\circ} 20.420^{\prime} \mathrm{N} \\
87^{\circ} 21.167^{\prime} \mathrm{W}\end{array}$ & 2 & wetland & 8.11 .2013 \\
\hline 7 & CRISTAL & $\begin{array}{l}20^{\circ} 12.023^{\prime} \mathrm{N} \\
87^{\circ} 29.993^{\prime} \mathrm{W}\end{array}$ & 5 & $\begin{array}{c}\text { sinkhole } \\
\text { (open) }\end{array}$ & 8.11 .2013 \\
\hline 8 & SIAN KA'AN & $\begin{array}{l}20^{\circ} 04.521^{\prime} \mathrm{N} \\
87^{\circ} 36.462^{\prime} \mathrm{W}\end{array}$ & 3.8 & lagoon & 8.11 .2013 \\
\hline
\end{tabular}

of the Yucatan Peninsula, SE Mexico (state of Quintana Roo). The studied cenotes are located between $20^{\circ} 04.521^{\prime} \mathrm{N}$ and $89^{\circ} 46.323^{\prime} \mathrm{W}$ (transect: Merida-Valladolid-TulumCancun). The geographical location of the lakes and their general description are presented (Fig. 1, Table 1).

\section{METHODS}

Studied samples were taken from the littoral zone of each of the cenotes by means of a zooplankton net ( $50 \mu \mathrm{m}$ mesh size). The material for the analysis of zooplankton and phytoplankton were collected horizontally by pulling the mesh along the littoral. The samples were preserved in $70 \%$ alcohol, and stored in a cool place. The specimens were identified under an OLYMPUS BX40 microscope following Elías-Gutiérrez et al. (1999; 2006), and Kotov et al. (2005).

\section{RESULTS}

Phytoplankton was predominant in the analyzed water samples from cenotes (Table 2). The abundance of zooplankton was very low, and significantly lower in "enclosed" deep cenotes (Samula, X-Keken). Copepoda species were present in all of the studied cenotes, and were the most abundant

Table 2

Occurrence of zooplankton and phytoplankton in waters of the studied cenote lakes in November 2013.

Zooplankton components (Cladocera, Copepoda,

Ostracoda and Testacida) and total phytoplankton: $(+)$ low, $(++)$ middle, $(+++)$ high abundance.

\begin{tabular}{|c|c|c|c|c|c|c|}
\hline No. & Name of lake & Cladocera & Copepoda & Ostracoda & Testacida & $\begin{array}{c}\text { Phyto- } \\
\text { plankton }\end{array}$ \\
\hline 1 & IK-KIL & ++ & ++ & & & + \\
\hline 2 & ZACI & & ++ & + & & + \\
\hline 3 & SAMULA & & + & + & & ++ \\
\hline 4 & X-KEKEN & & + & & & + \\
\hline 5 & ACTUM HA & ++ & ++ & + & + & +++ \\
\hline 6 & CHAN & + & ++ & + & + & +++ \\
\hline 7 & CRISTAL & + & + & ++ & ++ & +++ \\
\hline 8 & SIAN KA'AN & ++ & ++ & + & + & +++ \\
\hline
\end{tabular}



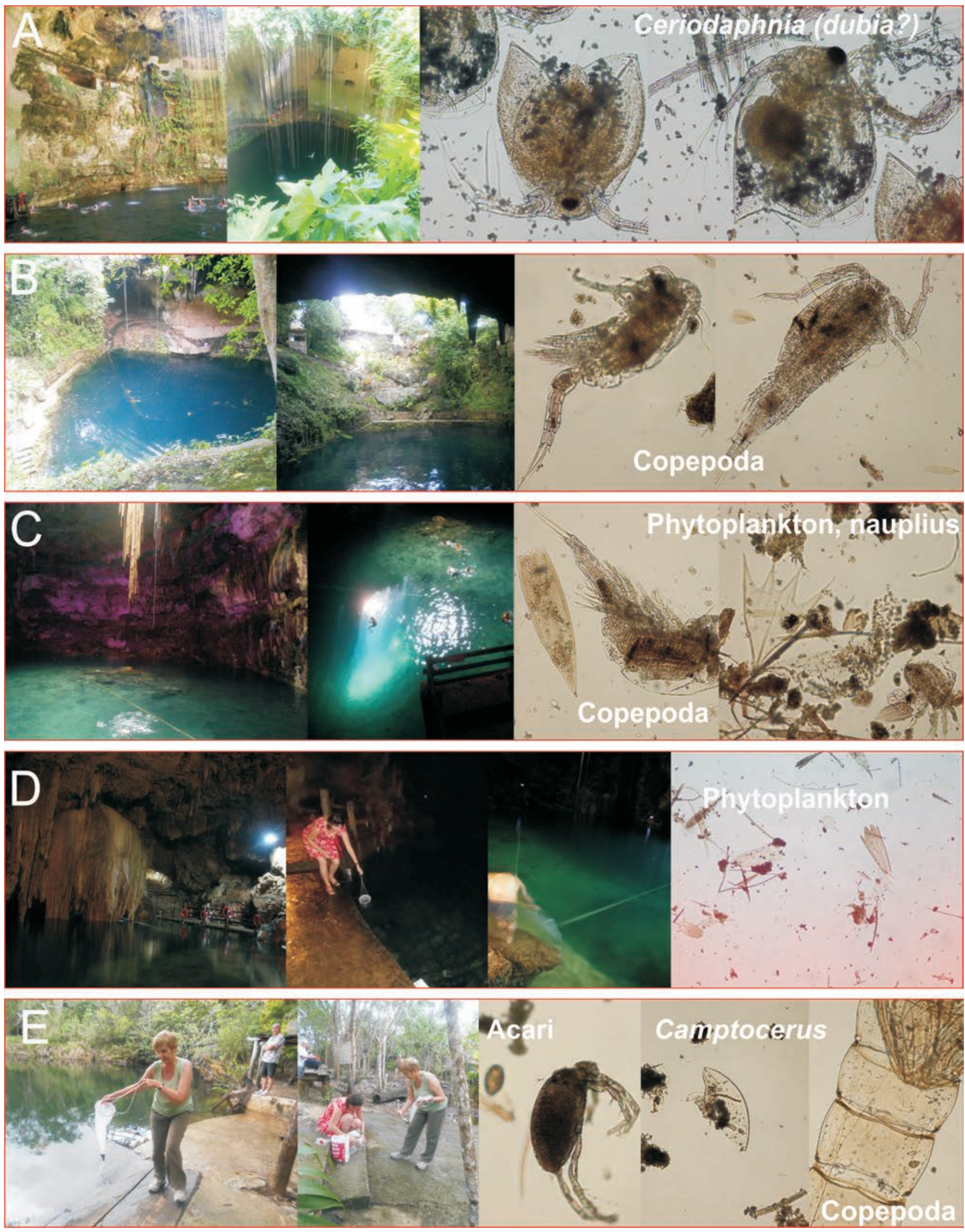

Fig. 2. Water sampling and examples of plankton findings. Cenotes: A-Ik-Kil, B - Samula, C-Zaci, D-X-Keken, E-Actum Ha.

component of zooplankton, followed by ostracods. Specimens of Testacida were present in four lakes (Table 2). Cladocera, which were the main author interest, was the less represented zooplankton group, presented only in five lakes
(Table 2). Among Cladocera only four taxa were found: Ceriodaphnia (dubia?), Alona sp., Camptocercus sp., Oxyurella sp. The deep sinkhole Ik-Kil showed high abundance of planktonic Ceriodaphnia (dubia?). The shallow open lakes: 

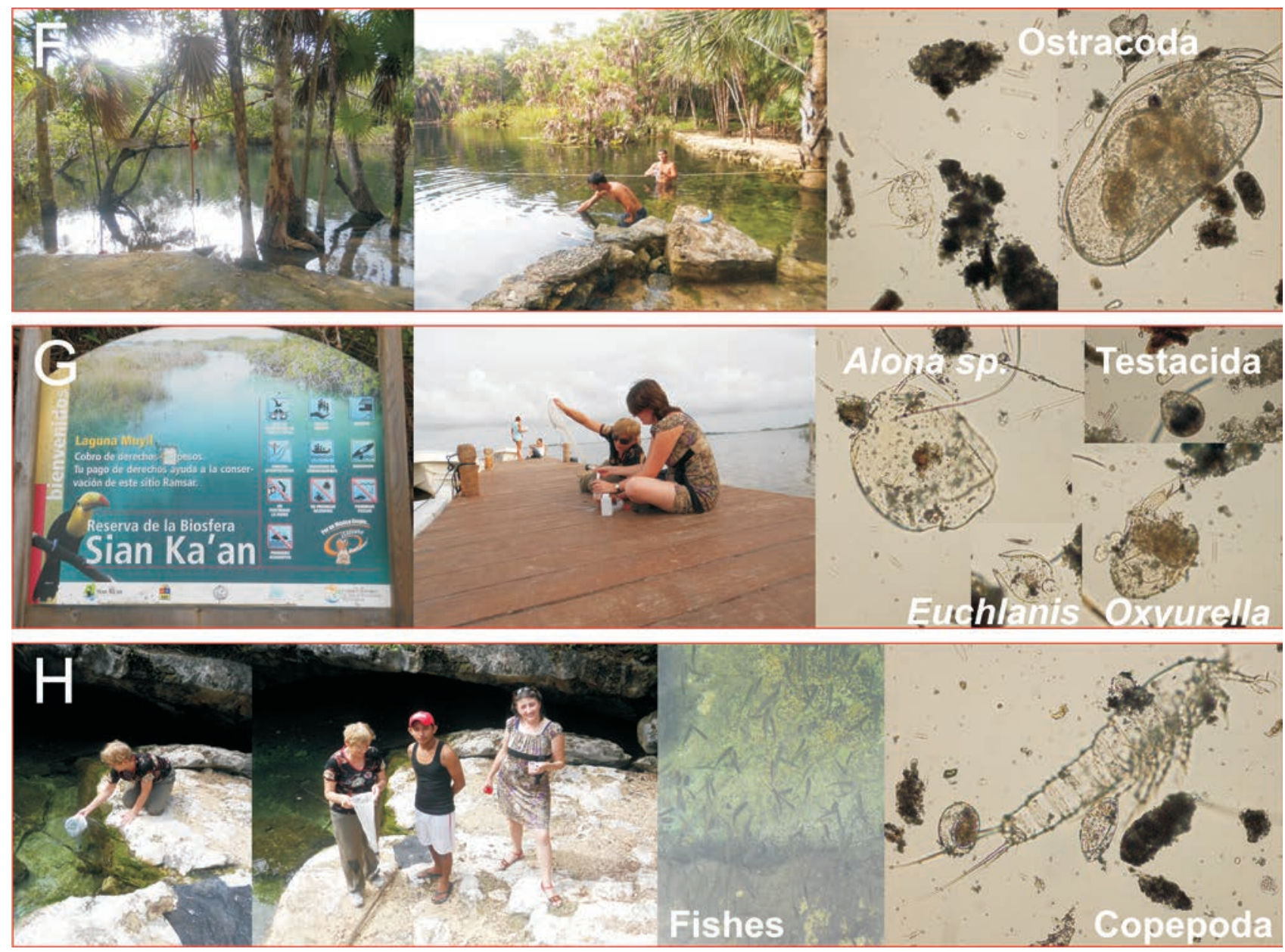

Fig. 2. Water sampling and examples of plankton findings. Cenotes: $\mathbf{F}-\mathrm{Cristal}, \mathbf{G}-\mathrm{Sian} \mathrm{Ka}$ 'an, $\mathbf{H}-\mathrm{Chan}$ Chemuxil.

Cris- tal, Actum Ha, Sian Ka'an, mostly showed presence of chydo- rids: Alona sp., Camptocercus sp. and Oxyurella sp. In the stu- died samples Alona sp. and Camptocercus sp. were only encountered as remains (shells and head shields). Examples of zoo- and phytoplankton found in the water samples are presented (Fig. 2).

\section{DISCUSSION}

The zooplankton species composition in water samples collected from eight cenotes with varied morphometry and lake type generally suggests low water trophy in all of the studied lakes and indicate their oligotrophic character. Cenotes showed varied degrees of development of plankton, and particularly phytoplankton at those lakes depending on the depth and extent of the open surface. In all studied lakes the species composition of zooplankton was generally quite poor. Cladocera species were very weakly represented. On the day of collection of water samples, deep-water fauna was only represented by Ceriodaphnia, and was only noted in the deepest cenote Ik-Kil. This may have various reasons, including very low content of nutrients, i.e. ultra-oligotrophic conditions, or high predatory pressure. It is possible that larger individuals of planktonic Cladocera (e.g. Daphnia) might be also intensively eaten by fish. The observed very low abundance of zooplankton in the collected samples might have been also influenced by the vertical migration of fauna. Cladoceran fauna frequently abides in deeper, darker parts of a lake during the day (it is less visible to fish), and migrates to the warmer and more abundant in food surface layer by night. The finding of remains (shells and head shields) in the water samples (Actum Ha and Sian Ka'an) is probably the results of resuspension of sediments. Those lakes are under tourist influence (people jumping into the water) what was widely observed during the collection of samples. This caused considerable water mixing and therefore resuspension of the non-consolidated material deposited on the lake bottom. The cenotes Samula, Zaci and X-Keken, showing the predominance of copepod individuals and rather scarce presence of phytoplankton species. It is possible that in those lakes the Cladocera could have been eaten by the numerously occurring Copepoda individuals. In the open lakes, both deeper and shallower, with considerably richer species composition of phytoplankton, Chlorophyceae were predominant, probably as a result of periodical (seasonal) slight increases in the water trophic status.

A similar result of poor species composition of aquatic fauna at cenotes was obtained in the scope of research by Smirnov and Elías-Gutiérrez (2011). The authors analysed among others the Cladocera species composition in the sediments of 25 cenotes. As the authors of the present study, they recorded no presence of Cladocera in several cenotes, among 
others in Zaci. The fact that the layer of surface sediments analysed by Smirnov and Elías-Gutiérrez had been deposited over several years suggests that the lack of cladoceran fauna in the lakes is not a result of predatory pressure, but rather oligotrophic conditions, which are unfavourable for the development of zooplankton. In shallow "open" cenotes, the authors recorded the presence of Cladocera represented by few littoral species. Their occurrence was manifested in the presence of remains (Camptocercus sp., Alona sp.). This could indicate that November is not a typical month for zooplankton development or may generally reflected weak representation of Cladocera in all cenotes. Results of analyses of phytoplankton and bacterioplankton obtained for cenotes (among others for holomictic Cristal and Actum Ha) by Torres-Talamante et al. (2011) and Sanchez et al. (2002), suggest that such low frequency of plankton has not depended on the date of sample collection, but much more on physical barriers developing in the limnic layers (thermocline, halocline, oxycline, or mixo- or chemo-limnion). As proved in studies of Lopez-Adrian (1994); Sarma and ElíasGutierrez (1999) and Gerd-Oltmann (2012) food webs in cenotes were quite simple and only several trophic levels occurred. Bacteria, fungi, algae, and protozoa constituted the first level, consumed by non-specialised micro and macroinvertebrates (Schmitter-Soto et al. 2002; Torres-Talamante 2011). The abundance of food was regulated by temperature. In many cenotes, the temperature of the source waters reflected the one of the meteoric/groundwaters (Torres-Talamante 2011). Some cenotes on the Yucatan Peninsula show a thermal anomaly where the temperature maximum is contained within the chemolimnion (Beddows et al. 2007; Stoessell et al. 1993; Stoessell et al. 2002; Torres-Talamante 2011). Low nutrient concentration determined by numerous authors, generally typical of the majority of cenotes, is also the reason for weak specimen representation of plankton, and particularly zooplankton (Cervantes-Martinez et al. 2002; Camargo-Guerra et al. 2013). The north-eastern part of the Yucatan Peninsula is poorly cultivated, and the population density is still low (Alcocer at al. 1998). In spite of increasing number of tourists (swimmers and divers), nutrient concentrations in waters of the cenotes is low, as reflected in a low density of phytoplankton and zooplankton. Due to the intensification of urbanisation and tourism in the Mexican Caribbean region (Cancum-Tulum tourist corridor), cenotes are of high importance not only as tourist objects, but most of all as drinking water resources. Therefore, they require continuous supervision and further biological research.

\section{Acknowledgments}

The study was funded by the Polish Ministry of Science (Grant NCN 2012/05/B/ST10/00469). This research was possible with a support of the Institute of Geological Sciences, Polish Academy of Sciences.

\section{REFERENCES}

Alcocer, J., Lugo, A. Luis, E.M., 1998. Hydrochemistry of water from five cenotes and evaluation of their suitability for drinking-water supplies, northern Yucatan, Mexico. J. Hydrogeol. 6: 293- 301.

Back, W., 1995. Water management by early people in the Yucatan,
Mexico. Envir. Geol. 25: 239-242.

Back, W., Hanshaw, W., 1970. Comparison of chemical hydrogeology of the carbonate peninsulas of Florida and Yucatan. J. Hydrol. 10: 119-130.

Beddows, P.A., Smart, P.L., Whitaker, F.F., Smith, S.L. 2007. Decoupled fresh-saline groundwater cccirculation of a coastal carbonate aquifer: spatial patterns of temperature and specific electrical conductivituy. Journal of Hydrology 346: 18-32.

Camargo-Guerra, T., Escalera-Vazquez, L.H., Zambrano, L., 2013. Fish community structure dynamics in cenotes if the Biosphere Reserve of Sian Ka'an, Yucatan Peninsula, Mexico. Revistana Maxicana de Biodiversidad, 84, 901-911.

Cervantes-Martinez, A., Elías-Gutiérrez, M., Suarez-Morales, E., 2002. Limnological snd morphometrical data of eight karstic systems 'cenotes' of the Yucatan Peninsula, Mexico, during the dry season. Hydrobiologia 482: 167-177.

Elías-Gutiérrez, M., Kotov, A.A., Garfias-Espejo T., 2006. Cladocera (Crustacea: Ctenopoda, Anomopoda) from southern Mexico, Belize and northern Guatemala. Zootaxa 1119: 1-27.

Elías-Gutiérrez, M., Ciros Perez, J., Suarez-Morales, E., Silva Briano M. 1999. The freshwater Cladocera (Crustacea, Ctenopoda and Anomopoda) of Mexico with comments on selected taxa. Crustaceana 72: 171-186.

Gerd-Oltmann, B., 2012. Distribution of some Canoida (Crustacea: Copepoda) from thr Yucatan Peninsula, Belize and Guatemala. Revista de Biologia Tropical, 60 (1): 187-202.

Kotov, A.A., Elías-Gutiérrez, M., Granados-Ramirez, J.G.. 2005. Moina dumonii sp. Nov. (Cladocera, Anomopoda, Moinidae) from Southern Mexico and Cuba, with Comments on Moinids Limbs, Crustaceana 78: 41-57.

Lopez-Adrian, S., Herrera-Silveira, J.A., 1994. Phytoplankton composition in a cenote, Yucatan, Mexico. Ver. int. Limnol. 25: 1402-1405.

Perry, E.C., Marin, L.E, Hall, F.G., 1996. The ring of cenotes (sinkholes) in northwest Yucatan, Mexico: its hydrogeologic characteristics and possible association with the Chicxulub impact crater. Geology, 23: 17-20.

Sarma, S.S.S., Elías-Gutiérrez, M., 1999. A survey on the rotifer (Rotatoria) fauna of the Yuacatan Peninsula (Mexico). Revista de Biologia Tropical, 47 (1): 187-196.

Sanchez, M., Alcocer, E., Escobar. E., Lugo, A., 2002. Phytoplankton of cenotes and anchialine caves along a distance gradient from northeastern coast of Quintana Roo, Yucatan Peninsula. Hydrobiologia 444467: 79-89.

Smirnov, N.N., Elías-Gutiérrez, M., 2011. Biocenotic Characteristics of Some Yucatan lentic Water Bodies Based on Invertebrate Remains in Sediments. Inland Water Biology, 4 (2): 2111-217.

Schmitter-Soto, J.J., Comin, F.A., Herrera-Silveira, J., Alcocer, J., Suarez-Morales, E., Elías-Gutiérrez, M., Diaz-Arce, V., Steinich, B., 2002. Hydrogeochemical and biological characteristics of cenotes in the Yucatan Peninsula (SE Mexico). Hydrobiologia 467: 215-228.

Steinich, B., Velazquez Oliman, G., Marin, L.E., Perry E. 1996. Determination of the ground water divide in the karst aquifer of Yucatan, Mexico, combining geochemical and hydrogeological data. Geofis. Int. 35:153-159.

Stoessell, R.K., Moore, Y.H., Coke, J.G., 1993. The occurrence and effect of sulfate oxidation on coastal limestone dissolution in Yucatan cenotes. Ground Water 31: 566-575.

Stoessell, R.K., Coke, J.G., Easley, D.H. 2002. Localized thermal anomalies in halocline of coastal Yucatan sinkholes. Ground Water 40: 416-424.

Torres-Talamante, O., Alcocer, J., Beddows, P.A., Escobar-Briones, E.G., Lugo, A. 2011. The key role of the chemolimnion in meromictic cenotes of the Yucatan peninsula, Mexico. Hydrobiologia 677: 107-127. 